Tohoku J. Exp. Med., 2004, 204, 99-107

\title{
Hyaluronate Inhibits the Interleukin-1 $\beta$-Induced Expression of Matrix Metalloproteinase (MMP)-1 and MMP-3 in Human Synovial Cells
}

\author{
Akiko Sasaki, Kan Sasaki, Yruö T. Konttinen, ${ }^{1}$ Seppo Santavirta, ${ }^{2}$ Masatoshi \\ Takahara, Hiroshi TAKei, Toshihiko Ogino and Michiaki Takagi \\ Department of Orthopedic Surgery, Yamagata University School of Medicine, \\ Yamagata, Japan, \\ ${ }^{1}$ Invärtes Medicine, Helsinki University Central Hospital, ORTON Orthopedic \\ Hospital, Invalid Foundation, Helsinki, Finland, and \\ ${ }^{2}$ Department of Orthopedics and Traumatology, Helsinki University Central \\ Hospital, Helsinki, Finland
}

Sasaki, A., Sasaki, K., Konttinen, Y.T., Santavirta, S., Takahara, M., Takei, H., Ogino, T. and TAKAGI, M. Hyaluronate Inhibits the Interleukin-1 $\beta$-Induced Expression of Matrix Metalloproteinase (MMP)-1 and MMP-3 in Human Synovial Cells. Tohoku J. Exp. Med., 2004, 204 (2), 99-107 — Intra-articular administration of hyaluronate (HA) is an effective treatment for arthritis. HA injections can decrease not only joint pain but also synovial effusion, although little is known concerning the mechanism of HA action. The aim of this study was to investigate the role of HA on the expression and production of matrix metalloproteinase (MMP) in synovial cells activated by interleukin (IL)- $1 \beta$ in order to achieve a better understanding of exogenous HA function in the extracellular matrix degradation in arthritic joints. Human synovial cells were incubated with HA $(0.1-1000 \mu \mathrm{g} / \mathrm{ml})$ and/or IL-1 $\beta(1 \mathrm{ng} / \mathrm{ml})$. The expression of MMP-1 and MMP-3 mRNAs was analyzed by quantitative realtime polymerase chain reaction. The protein levels of MMP-1 and MMP-3 in cultured media were measured by immunoblotting. Expression of MMP-1 and MMP-3 mRNAs was induced by IL- $1 \beta$. The IL- $1 \beta$-mediated induction of MMP- 1 mRNA expression was attenuated by $10 \mu \mathrm{g} / \mathrm{ml} \mathrm{HA}(p=0.026)$ and that of MMP-3 mRNA was strongly down-regulated in the presence of 10 or $1000 \mu \mathrm{g} / \mathrm{ml} \mathrm{HA}(p<0.001)$. The increased protein levels of MMP-1 and MMP-3 were also reduced by 1000 $\mu \mathrm{g} / \mathrm{ml}$ HA. These data suggest that HA inhibits the expression and production of MMP-1 and MMP-3 in IL- $1 \beta$-stimulated human synovial cells. We therefore prepose that intra-articular HA may rescue inflamed joints from bone and cartilage destruction by reducing the production of MMP-1 and MMP-3. - - Hyaluronate; interleukin-1 $\beta$; human synovial cells; matrix metalloproteinases; tissue inhibitor of metalloproteinases

(C) 2004 Tohoku University Medical Press

Received December 8, 2003; revision accepted for publication July 13, 2004.

Address for reprint: Akiko Sasaki, M.D., Department of Orthopaedic Surgery, Yamagata University School of Medicine, 2-2-2 Iida Nishi, Yamagata 990-9585, Japan.

e-mail: aksasaki@med.id.yamagata-u.ac.jp 
Degradation of the articular component is characterized by continuous joint inflammation, particularly in rheumatoid arthritis (RA) (Harris 1990). Arthritic synovial fluid contains many kinds of proinflammatory cytokines. Interleukin (IL) $-1 \beta$ has been reported to be one of the most important inflammatory mediators (Buchan et al. 1988; Koch et al. 1995). It stimulates production of other cytokines and extra-cellular matrix degrading enzymes (Mizel et al. 1981; Dinarello et al. 1987). Matrix metalloproteinases (MMPs) are a family of zinc-dependent endopeptidases, which are able to degrade almost all components of the extra-cellular matrix (Nagase and Woessner 1999). They have been considered to play a key role in the degradation of the cartilage matrix in arthritic joints (Konttinen et al. 2000). The enzymatic activities of these MMPs are strictly controlled by tissue inhibitors of metalloproteinases (TIMPs). TIMPs not only inhibit the activity of MMPs by binding to them in an irreversible $1: 1$ noncovalent complex (Murphy and Willenbrock 1995), but also modulate the production and activity of MMPs. Activated synovial cells in inflammation produce various types of MMPs, including collagenase-1 (MMP-1) and stromelysin-1 (MMP-3) (Okada et al. 1989; Konttinen et al. 2000). An imbalance of MMPs and TIMPs has been hypothesized to contribute to joint destruction in arthritis (MacNaul et al. 1990; MartelPelletier et al. 1994; Burger et al. 1998).

Hyaluronate (HA) is an important component of the articular cartilage matrix. Joint fluid also contains HA, which contributes to the mixed mode lubrication of the joint (Balazs et al. 1967). Intra-articular injection of exogenous $\mathrm{HA}$ is one of the treatment options for arthritis, HA decreases pain (Rydell and Balazs 1971), and improves joint function (Altman and Moskowits 1998). Injected HA has not only physical protective effects, but also physiological effects in the joint, that is the down regulation of chemical mediators which cause pain or inflammation, such as arachidonic acid (Tobetto et al. 1992) and prostaglandin $\mathrm{E}_{2}$ (Punzi et al. 1989; Yasui et al. 1992). However, the mechanisms of exogenous HA on joint degradation have not been completely clarified.

The aim of the present study was to investigate the effect of HA on the expression and production of MMPs and TIMPs in human synovial cells stimulated by IL- $1 \beta$.

\section{Materials And Methods}

\section{Cell culture}

Human synovial stromal cells were obtained from Cell Systems Corporation (Kirkland, WA, USA). These cells were maintained in a Cell Systems Corporation serum free medium (CS-C serum free medium) (Cell Systems Corporation), which contained 25\% Dulbecco's modified Eagle's medium (DMEM), 25\% Ham's F-12 and $50 \%$ MCDB153 supplemented with $1 \mathrm{mg} / \mathrm{ml}$ human serum albumin and human lipoprotein. Cells were grown and maintained at $37^{\circ} \mathrm{C}$ in a humidified atmosphere of $5 \% \mathrm{CO}_{2}$ in $15 \mathrm{ml} \mathrm{CS-C}$ serumfree medium in $75 \mathrm{~cm}^{2}$ culture flasks (Greiner Bio-One, Frickenhausen, Germany) until confluent. Third to fourth passage cells were used in the experiments. The cells were seeded into 6-well plates (Becton Dickinson and Company, Franklin Lakes, NJ, USA) at a density of $3 \times 10^{5}$ cells/well in CS-C serum free medium. After 24 hours, the cells were exposed to IL- $1 \beta$ (R\&D Systems, Minneapolis, MN, USA) and sodium hyaluronate (molecular weight: $9 \times 10^{5} \mathrm{Da}$ ) (Seikagaku Kogyo, Tokyo). The cultured media were kept at $-80^{\circ} \mathrm{C}$ until the protein analysis was performed.

RNA extraction and quantitative real-time reverse transcriptase-polymerase chain reaction (RT-PCR)

Total RNA was isolated using an ISOGEN kit (Nippongene, Tokyo). The quantity of RNA was estimated by spectrophotometry at $260 \mathrm{~nm}$. Complementary deoxyribonucleic acid (cDNA) was produced by reverse-transcription. Enzymatic amplification of the specific cDNA sequences was performed in a Lightcycler (Roche Diagnostics, Mannheim, Germany) as second-step PCR, as described previously (Sasaki et al. 2001). 
Quantification was based on a comparison of the fluorescence of the PCR product with the fluorescence of several dilutions of an external standard. Plasmids (for MMPs) and purified PCR products (for TIMPs) diluted into six different concentrations were used as external standards. Beta-actin was used as an internal standard. The ratios of MMPs or TIMPs to beta-actin were calculated. The primers for TIMPs were designed with online software (Primer 3; Whitehead Institute for Biomedical Research, Cambridge, MA, USA) or taken from previous reports (Takei et al. 2000).

\section{Immunoblotting}

The cultured media were diluted $1: 1$ in a sample buffer $(0.5 \mathrm{M}$ Tris- $\mathrm{HCl}, \mathrm{pH} 6.8,4 \%$ sodium dodecyl sulfate, $20 \%$ glycerol, $0.05 \%$ bromphenol blue, and $1.2 \% \beta$-mercaptoethanol), and applied to $10 \%$ sodium dodecyl sulfate polyacrylamide gels for electrophoresis (15 $\mu$ l/lane). Proteins were then electrophoretically transferred to nitrocellulose membranes (Bio-Rad Laboratories, Richmond, CA, USA) as described previously (Takagi et al. 1998). The blotted membrane was incubated with monoclonal mouse anti-human MMP-1 $(0.5 \mu \mathrm{g} / \mathrm{ml}$ in $0.05 \%$ Tween 20 -Tris buffered saline, pH 7.5, Daiichi Fine Chemical Co., Toyama), or MMP-3 $(1 \mu \mathrm{g} / \mathrm{ml}$ in $0.05 \%$ Tween 20-Tris buffered saline, pH 7.5, Daiichi Fine Chemical Co.) for one hour at room temperature. After washing three times, the membrane was incubated with alkaline phosphatase-conjugated goat anti-mouse IgG $(1: 1000$ dilution in $0.05 \%$ Tween 20-Tris buffered saline, Sigma Aldorich Co., St. Louis, MO, USA) for $30 \mathrm{~min}-$ utes at room temperature. After two washes with $0.1 \%$ Tween 20 -Tris buffered saline, alkaline phosphatase binding sites were revealed in $10 \mathrm{ml}$ of alkaline phosphatase buffer $(100 \mathrm{mM} \mathrm{NaCl}, 5$ $\mathrm{mM} \mathrm{MgCl}_{2}$, and $100 \mathrm{mM}$ Tris- $\mathrm{HCl}, \mathrm{pH} 9.5$ ) with a combination of $16.5 \mu 1$ nitro blue tetrazolium solution $(30 \mathrm{mg} / \mathrm{ml}$ in $90 \%$ dimethylformamide; Sigma Aldorich Co.) and $8.25 \mu 1$ of 5-bromo-4chloro-3-indolyl phosphate solution $(50 \mathrm{mg} / \mathrm{ml}$; Roche Diagnostics). US National Institutes of
Health image software was to compare immunoreactive band densities.

\section{Statistical analysis}

The mean and standard error of the mean (SEM: Microsoft ${ }^{\circledR}$ Excel 2001, Microsoft Co.) of the standardized mRNA expression level was calculated from results obtained from tripricate experiments. The ratios of MMPs or TIMPs to betaactin were calculated. Statistical differences between the test conditions and controls were analyzed using analysis of variance (ANOVA). Significance of multiple comparisons was assessed using a post hoc examination with Scheffe's F test (Statview, Abascus Concepts Inc., Berkeley, CA, USA). A value of $p<0.05$ was regarded as statistically significant. Pearson's correlation coefficient ( $r$ ) was calculated for all standard curves to evaluate proper PCR performance with an external control (Sasaki et al. 2001).

\section{RESUlts}

Effect of IL-1 $\beta$ and/or HA of MMP and TIMP $m R N A$ expression in synovial cells

MMP-1, MMP-3, TIMP-1, TIMP-2 and betaactin cDNAs were appropriately amplified in all experiments. The value of the cDNA concentration was calculated by linear regression of standard curves. The level of MMP-1 mRNA was increased by IL- $1 \beta$ after 6 hours (the ratio to control was 3.56 $\pm 0.27, p=0.0052$ ) (Fig. $1 \mathrm{~A}$ ). The degree of MMP-1 mRNA induction was transiently reduced by HA $(10 \mu \mathrm{g} / \mathrm{ml})$ at 12 hours (the ratio to the control was $3.14 \pm 0.58$ in the presence of HA and 5.76 \pm 0.26 in its absence, $p=0.026$ ). Likewise, HA $(1000 \mu \mathrm{g} / \mathrm{ml})$ tended to decrease the elevated mRNA expression of MMP-1 after 12 hours (12 hours; the ratio to the control was $4.58 \pm 0.45$ in the presence of HA and IL- $1 \beta$ and $5.76 \pm 0.26$ in the presence of only IL- $1 \beta$, with the corresponding figures at 24 hours being $3.60 \pm 0.82$ and $4.26 \pm$ $1.03)$, although the differences were not statistically significant. MMP-3 mRNA expression was up-regulated by IL- $1 \beta$ in a time-dependent manner (Fig. 1B). The IL-1 $\beta$-stimulated level of 
Fig. 1A.

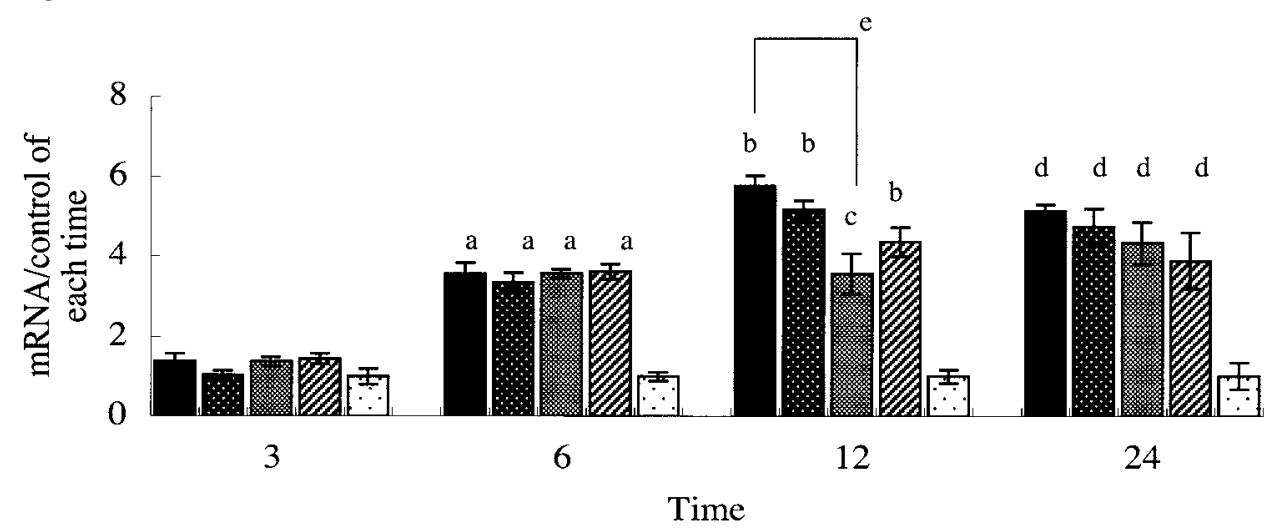

Fig. 1B.

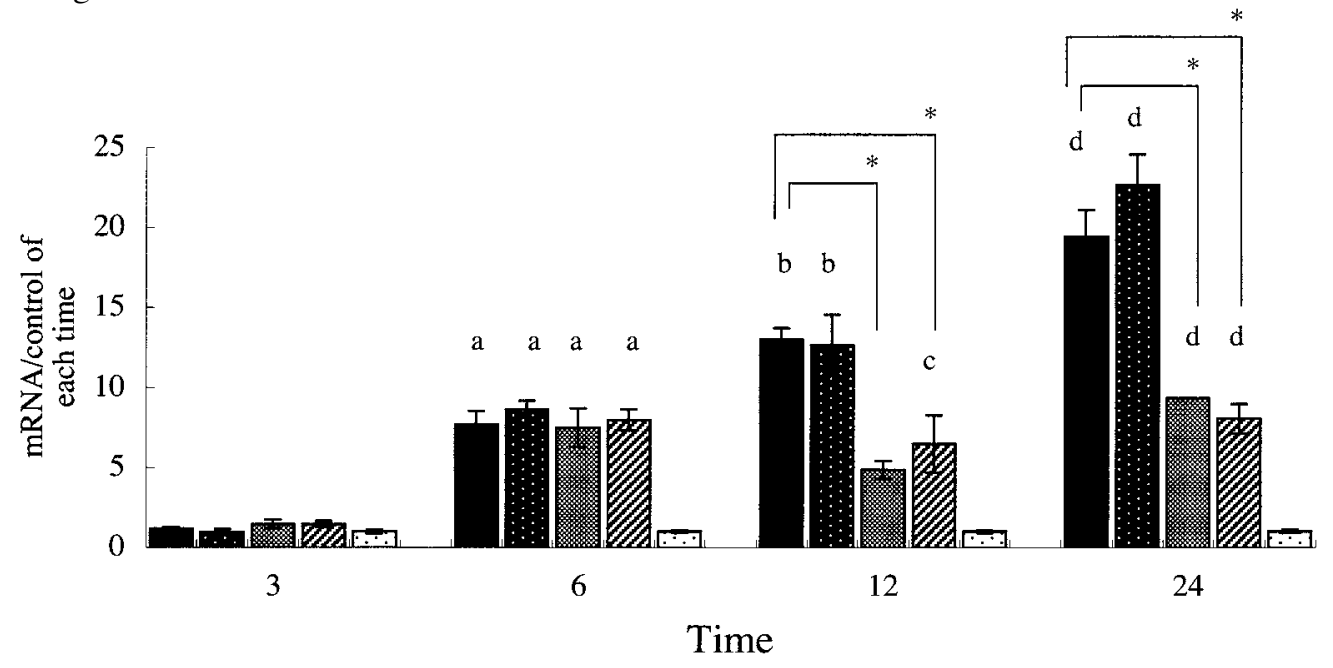

Fig. 1. The effect of IL- $1 \beta$ and HA on MMP-1 and MMP-3 mRNA expression.

Human synovial cells were cultured in the absence or presence of IL- $1 \beta(1 \mathrm{ng} / \mathrm{ml})$ and $\mathrm{HA}(0,0.1$, 10 and $1000 \mu \mathrm{g} / \mathrm{ml}$ ) for 3, 6, 12 and 24 hours. Y-axis indicates the ratio to the control each time. Values are shown as the mean \pm s.D. $\left(\right.$ Microsoft ${ }^{\circledR}$ Excel 2001, Microsoft Corporation, Redmond, WA, USA). The mRNA level of MMP- 1 was up-regulated by IL- $1 \beta$ at 6 hours. At 12 hours, the IL- $1 \beta$ induced level of MMP-1 mRNA was transiently reduced by HA $(10 \mu \mathrm{g} / \mathrm{ml})$ (Fig. 1A). MMP-3 mRNA expression was more efficiently up-regulated by IL- $1 \beta$ in a time-dependent manner. The IL- $1 \beta$-induced expression of MMP-3 mRNA was decreased by 10 and $1000 \mu \mathrm{g} / \mathrm{ml} \mathrm{HA}$ at 12 and 24 hours (Fig. 1B). Treatment with $0.1 \mu \mathrm{g} / \mathrm{ml}$ HA had no noticeable effects on the IL- $1 \beta$-effects (Figs. $1 \mathrm{~A}$ and $1 \mathrm{~B})(n=3)$.

, indicates IL-1 $\beta(1 \mathrm{ng} / \mathrm{ml})$; , indicates IL-1 $\beta(1 \mathrm{ng} / \mathrm{ml})$ and $\mathrm{HA}(0.1 \mu \mathrm{g} / \mathrm{ml})$ , indicates IL-1 $\beta(1 \mathrm{ng} / \mathrm{ml})$ and HA $(10 \mu \mathrm{g} / \mathrm{ml})$; שIIIA , indicates IL- $\beta(1 \mathrm{ng} / \mathrm{ml})$ and HA $(1000 \mu \mathrm{g} / \mathrm{ml})$; $\therefore$, indicates only culture media.

${ }^{\mathrm{a}} p<0.01$ vs. 6 hours control, ${ }^{\mathrm{b}} p<0.01$ vs. 12 hours control, ${ }^{\mathrm{c}} p<0.05$ vs. 12 hours control, ${ }^{\mathrm{d}} p<0.01$ vs. 24 hours control, ${ }^{\mathrm{e}} p<0.05$ between the columns indicated with brackets. 
MMP-3 mRNA expression was over ten-fold higher than the corresponding control (24 hours; the ratio to the control was $18.34 \pm 2.24, p<0.001$ ). The IL- $1 \beta$-mediated induction of MMP-3 mRNA was effectively decreased by HA (10 and 1000 $\mu \mathrm{g} / \mathrm{ml}$ ) at 12 and 24 hours (the ratios to control were at 12 hours $4.85 \pm 0.56$ in $10 \mu \mathrm{g} / \mathrm{ml} \mathrm{HA}$ and IL- $1 \beta, 6.47 \pm 1.79$ in $1000 \mu \mathrm{g} / \mathrm{ml}$ HA and IL- $1 \beta$, $13.01 \pm 0.71$ in IL- $1 \beta$; and at 24 hours $9.35 \pm 0.04$ in $10 \mu \mathrm{g} / \mathrm{ml} \mathrm{HA}$ and IL- $1 \beta, 8.05 \pm 0.93$ in 1000 $\mu \mathrm{g} / \mathrm{ml} \mathrm{HA}$ and IL- $1 \beta, 18.34 \pm 2.24$ in IL- $1 \beta$ ). In contrast, expression of TIMP-1 and TIMP-2 mRNAs was not significantly affected by IL- $1 \beta$ or HA (data not shown). HA at a lower concentration $(0.1 \mu \mathrm{g} / \mathrm{ml})$ had no influence on the IL- $1 \beta$ -enhanced mRNA expression of MMP-1 and MMP-3 mRNAs (Figs. 1A and 1B). HA by itself alone did not modulate the mRNA expression of MMP-1 and MMP-3 (data not shown).

\section{Protein level analysis of MMP-1 and MMP-3 in cultured media}

MMP-1 and MMP-3 immunoreactive proteins were detected in IL- $1 \beta$-stimulated cultured media after 24 hours. Increased production of MMP-1 protein was decreased by $1000 \mu \mathrm{g} / \mathrm{ml} \mathrm{HA}$ $(p=0.017)$. HA $(10 \mu \mathrm{g} / \mathrm{ml})$ tended to reduce production of MMP-1, but there was no significant difference (Fig. 2A). MMP-3 was reduced by HA $(1000 \mu \mathrm{g} / \mathrm{ml})$ at 24 hours $(p=0.037)$ (Fig. $2 \mathrm{~B})$.

\section{Discussion}

We investigated the effect of HA (molecular weight; $9 \times 10^{5} \mathrm{Da}$ ) at concentrations ranging from 0.1 to $1000 \mu \mathrm{g} / \mathrm{ml}$, because high molecular weight HA (range from $9 \times 10^{5}$ to $2 \times 10^{6} \mathrm{Da}$ ) is usually used for intra-articular injections in arthritis. And we demonstrated that HA (10 or $1000 \mu \mathrm{g} / \mathrm{ml})$ reduces MMP-1 and MMP-3 levels stimulated by IL- $1 \beta$ in mRNA and protein released into the cultured media. Biologically, synovial fluid in normal human joints contains high concentrations of HA ( 2 to $4 \mathrm{mg} / \mathrm{ml}$ ), the molecular weight of which ranges from $1 \times 10^{6}$ to $10^{7} \mathrm{Da}$ (Dahl et al. 1985). The concentration of HA used in this study (10 $\mu \mathrm{g} / \mathrm{ml})$ is much lower than the concentration of HA in normal synovial fluid (Saari and Konttinen 1989). Our data suggest that HA regulates the mRNA expression and protein production of MMP-1 and MMP-3 even at low concentrations. According to previous reports, high molecular weight HA has multiple effects on synovial cells in vitro, including an anti-inflammatory effect (Punzi et al. 1989; Yasui et al. 1992) and inhibitory potential on the expression of MMP-1 and MMP-3 in articular cartilage (Julovi et al. 2004). MMP-1 and MMP-3 are considered to play important roles in arthritis (McCachren 1991; Cunnane et al. 2001). Inflammatory synovial cells produce high levels of MMPs in arthritic joints (Konttinen et al. 1999). This causes degradation of articular cartilage and even subchondral bone, especially in rheumatoid arthritis. Indeed, elevated protein and/or mRNA levels of MMP-1 and MMP-3 have been detected in synovial fluid and membrane (Gravallese et al. 1991; Yoshihara et al. 2000). Furthermore, the production of TIMP-1 and TIMP-2 in synovial fluid is also high in rheumatoid arthritis compared with normal synovial fluid, but not as high as MMPs (Ishiguro et al. 2001). As a result of such an MMP-to-TIMP imbalance, degradation of bone and cartilage are accelerated (Burger et al. 1998).

On the other hand, activated synovial cells produce joint fluid containing abundant chemical mediator such as IL- $1 \beta$. We confirmed that IL- $1 \beta$ up-regulates mRNA expression and protein production of MMP-1 and MMP-3 in cultured human synovial cells. Consequently, an imbalance of MMPs and TIMPs, probably contributing to MMP-3-mediated activation of proMMP-1, and unopposed by their endogenous TIMP inhibitors, seems to be evoked as a result of stimulation. This seems to be an in vitro equivalent of inflammatory conditions in human synovial joints in vivo, and is compatible with previous reports (Postlethwaite et al. 1983; DiBattista et al. 1995). The IL- $1 \beta$-stimulated mRNA expression of MMP-1 and MMP-3, but not TIMP-1 and TIMP-2, was effectively inhibited by high molec- 
Fig. 2A.

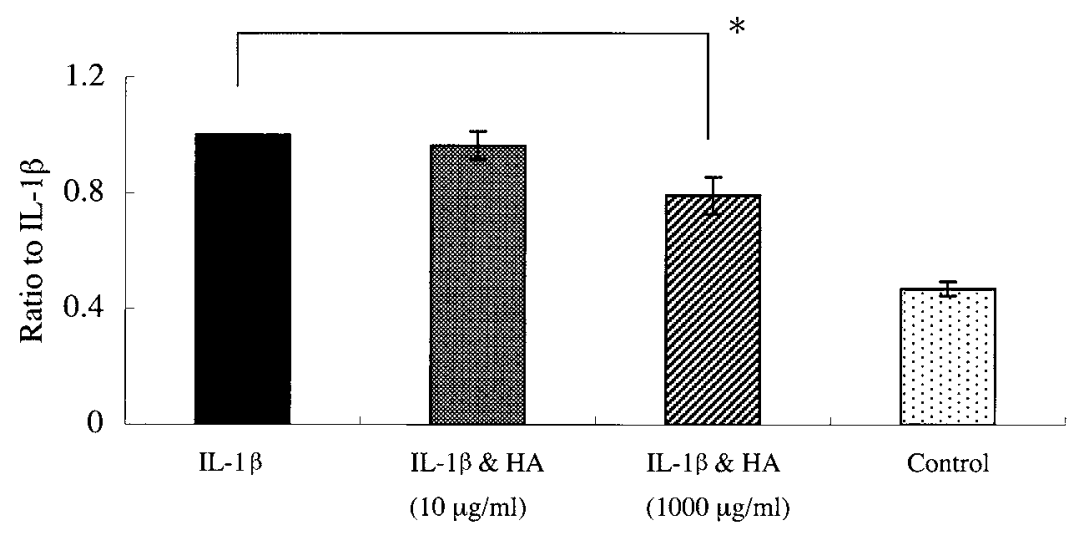

Fig. 2B.

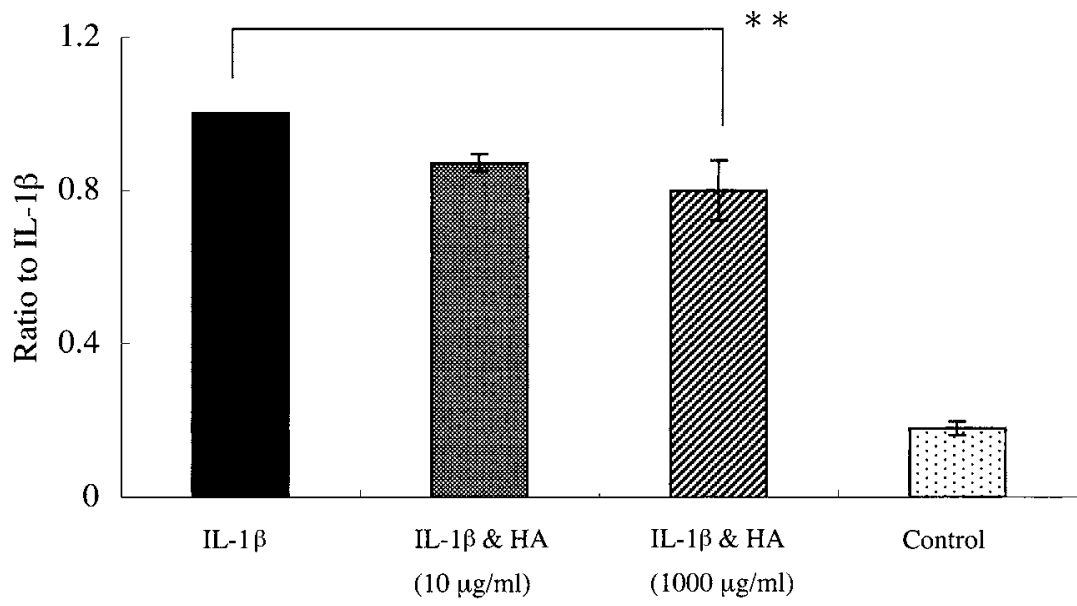

Fig. 2. Immunoblot of MMP-1 and MMP-3 stimulated with IL-1 $\beta$ and/or HA.

Immunoreactive MMP- 1 and MMP- 3 were detected in the culture media of IL- $1 \beta$-stimulated cells after 24 hours. Increased protein levels of MMP-1 and MMP-3 in the supernatant after 24 hours were reduced by HA $(1000 \mu \mathrm{g} / \mathrm{ml})$. The levels of protein were compared between IL- $1 \beta$-stimulated synovial cells with or without HA (10 and $1000 \mu \mathrm{g} / \mathrm{ml})$ by densitometric analysis $(n=3)$.

, indicates IL-1 $\beta(1 \mathrm{ng} / \mathrm{ml})$; indicates IL-1 $\beta(1 \mathrm{ng} / \mathrm{ml})$ and HA $(10 \mu \mathrm{g} / \mathrm{ml})$; $\mathbb{Z}$, indicates IL-1 $\beta(1 \mathrm{ng} / \mathrm{ml})$ and $\mathrm{HA}(1000 \mu \mathrm{g} / \mathrm{ml}) ; \therefore$, indicates only culture media. " $p=0.017,{ }^{*} p=0.037$.

ular weight HA in human synovial cells. This effect may correct the MMP-to-TIMP imbalance, particularly with high levels of MMPs under inflamed conditions.

The mechanisms responsible for HAmediated down-regulation of the expression of MMPs in synovial cells are still unclear. HA may inhibit binding of IL- $1 \beta$ to its membrane-bound receptor by covering the cell surface, thereby suppressing the production of MMPs. HA also may inhibit signal transduction through HA receptors such as CD44 (Shimizu et al. 2003; Julovi et al. 2004) or the receptor for hyaluronan-mediated motility (RHAMM) (Entwistle et al. 1996). These receptors have been reported to perform separate functions. The binding of HA to CD44 modulates cell adhesion and proliferation (Masellis-Smith et al. 1996). In contrast, the binding of HA to RHAMM regulates cell migration (Savani et al. 2001). These effects were ob- 
tained only with low molecular weight $\left(2 \times 10^{4}\right.$ to $\left.4 \times 10^{5} \mathrm{Da}\right) \mathrm{HA}$, which has been reported to display proinflammatory activities; for example, stimulating the expression of nuclear factor- $\kappa \mathrm{B}$ $(\mathrm{NF}-\kappa \mathrm{B})$-dependent genes such as TNF- $\alpha$ and IL-1 $\beta$ (Noble et al. 1993). On the contrary, high molecular weight HA exhibits different biological activities and inhibits the expression of $N F-\kappa B$ via interference with its inducer (Neumann et al. 1999). $\mathrm{NF}-\kappa \mathrm{B}$ is a transcription factor well known for its essential role in MMPs production and secretion (Bond et al. 1999). However, it has not been clarified whether down-regulation of MMP-1 and MMP-3 in human synovial cells is mediated through signal transduction of $\mathrm{NF}_{-} \kappa \mathrm{B}$.

In conclusion, our data suggest that HA decreases mRNA expression and protein production of the tissue destructive MMP-1/MMP-3 cascade without any effect on the endogenous proteinase inhibitor shield in human synovial cells stimulated by IL- $1 \beta$. Therefore, HA can suppress pathologic extracellular matrix degradation in arthritic joints and delay progressive joint degradation through down-regulation of the production of MMP-1 and MMP-3 in IL- $1 \beta$-stimulated synovial cells.

\section{References}

Altman, R.D. \& Moskowitz, R. (1998) Intraarticular sodium hyaluronate (Hyalgan) in the treatment of patients with osteoarthritis of the knee: a randomized clinical trial. J. Rheumatol., 25, 2203-2212.

Balazs, E.A., Watson, D., Duff, I.F. \& Roseman, S. (1967) Hyaluronic acid in synovial fluid. I. Molecular parameters of hyaluronic acid in normal and arthritis human fluids. Arthritis. Rheum., 10, 357-376.

Bond, M., Baker, A.H. \& Newby, A.C. (1999) Nuclear factor kappaB activity is essential for matrix metalloproteinase-1 and -3 upregulation in rabbit dermal fibroblasts. Biochem. Biophys. Res. Commun., 264, 561-567.

Burger, D., Rezzonico, R., Li, J.M., Modoux, C., Pierce, R.A. \& Welgus, H.G. (1998) Imbalance between interstitial collagenase and tissue inhibitor of metalloproteinases 1 in synoviocytes and fibroblasts upon direct contact with stimulated T lymphocytes: involvement of mem- brane-associated cytokines. Arthritis. Rheum., 41, 1748-1759.

Buchan, G., Barrett, K., Turner, M., Chantry, D., Maini, R.N. \& Feldmann, M. (1988) Interleukin-1 and tumour necrosis factor mRNA expression in rheumatoid arthritis: prolonged production of IL-1 alpha. Clin. Exp. Immunol., 73, 449-455.

Cunnane, G., Fitzgerald, O., Beeton, C., Cawston, T.E. \& Bresnihan, B. (2001) Early joint erosions and serum levels of matrix metalloproteinase 1, matrix metalloproteinase 3 , and tissue inhibitor of metalloproteinases 1 in rheumatoid arthritis. Arthritis. Rheum., 44, 2263-2274.

Dahl, L.B., Dahl, I.M., Engstrom-Laurent, A. \& Granath, K. (1985) Concentration and molecular weight of sodium hyaluronate in synovial fluid from patients with rheumatoid arthritis and other arthropathies. Ann. Rheum. Dis., 44, 817-822.

DiBattista, J.A., Pelletier, J.P., Zafarullah, M., Fujimoto, N., Obata, K. \& Martel-Pelletier, J. (1995) Coordinate regulation of matrix metalloproteases and tissue inhibitor of metalloproteinase expression in human synovial fibroblasts. J. Rheumatol. Suppl., 43, 123-128.

Dinarello, C.A., Ikejima, T., Warner, S.J., Orencole, S.F., Lonnemann, G. \& Cannon, J.G. (1987) Interleukin 1 induces interleukin 1. I. Induction of circulating interleukin 1 in rabbits in vivo and in human mononuclear cells in vitro. $J$. Immunol., 139, 1902-1910.

Entwistle, J., Hall, C.L. \& Turley, E.A. (1996) HA receptors: regulators of signalling to the cytoskeleton. J. Cell. Biochem., 61, 569-577.

Gravallese, E.M., Darling, J.M., Ladd, A.L., Katz, J.N. \& Glimcher, L.H. (1991) In situ hybridization studies of stromelysin and collagenase messenger RNA expression in rheumatoid synovium. Arthritis. Rheum., 34, 1076-1084.

Harris, E.D. (1990) Rheumatoid arthritis. Pathophysiology and implication for therapy. N. Engl. J. Med., 322, 1277-1289.

Ishiguro, N., Ito, T., Oguchi, T., Kojima, T., Iwata, H. \& Ionescu, M. (2001) Relationships of matrix metalloproteinases and their inhibitors to cartilage proteoglycan and collagen turnover and inflammation as revealed by analyses of synovial fluids from patients with rheumatoid arthritis. Arthritis. Rheum., 44, 2503-2511.

Julovi, S.M., Yasuda, Y., Shimizu, M. Hiramitsu, T. \& Nakamura, T. (2004) Inhibition of interleukin-1 
$\beta$-stimulated production of matrix metalloproteinases by hyaluronan via CD44 in human articular cartilage. Arthritis. Rheum., 50, 516-525.

Koch, A.E., Kunkel, S.L. \& Strieter, R.M. (1995) Cytokines in rheumatoid arthritis. J. Investig. Med., 43, 28-38.

Konttinen, Y.T., Ainola, M., Valleala, H., Ma, J., Ida, H. \& Mandelin, J. (1999) Analysis of 16 different matrix metalloproteinases (MMP-1 to MMP-20) in the synovial membrane: different profiles in trauma and rheumatoid arthritis. Ann. Rheum. Dis., 58, 691-697.

Konttinen, Y.T., Li, T.F., Mandelin, J., Liljestrom, M., Sorsa, T. \& Santavirta, S. (2000) Increased expression of extracellular matrix metalloproteinase inducer in rheumatoid synovium. Arthritis. Rheum., 43, 275-280.

MacNaul, K.L., Chartrain, N., Lark, M., Tocci, M.J. \& Hutchinson, N.I. (1990) Discoordinate expression of stromelysin, collagenase, and tissue inhibitor of metalloproteinases- 1 in rheumatoid human synovial fibroblasts. Synergistic effects of interleukin-1 and tumor necrosis factor-alpha on stromelysin expression. J. Biol. Chem., 265, 17238-17245.

Martel-Pelletier, J., McCollum, R., Fujimoto, N., Obata, K., Cloutier, J.M. \& Pelletier, J.P. (1994) Excess of metalloproteases over tissue inhibitor of metalloprotease may contribute to cartilage degradation in osteoarthritis and rheumatoid arthritis. Lab. Invest., 70, 807-815.

Masellis-Smith, A., Belch, A.R., Mant, M.J., Turley, E.A. \& Pilarski, L.M. (1996) Hyaluronan-dependent motility of B cells and leukemic plasma cells in blood, but not of bone marrow plasma cells, in multiple myeloma: alternate use of receptor for hyaluronan-mediated motility (RHAMM) and CD44. Blood, 87, 1891-1899.

McCachren, S.S. (1991) Expression of metalloproteinases and metalloproteinase inhibitor in human arthritic synovium. Arthritis. Rheum., 34, 1085-1093.

Mizel, S.B., Dayer, J.M., Krane, S.M. \& Mergenhagen, S.E. (1981) Stimulation of rheumatoid synovial cell collagenase and prostaglandin production by partially purified lymphocyte-activating factor (interleukin 1). Proc. Natl. Acad. Sci. USA, 78, 2474-2477.

Murphy, G. \& Willenbrock, F. (1995) Tissue inhibitors of matrix metalloendopeptidases. Methods. Enzymol., 248, 496-510.

Nagase, H. \& Woessner, J.F., Jr. (1999) Matrix metal- loproteinases. J. Biol. Chem., 274, 2149121494.

Neumann, A., Schinzel, R., Palm, D., Riederer, P. \& Munch, G. (1999) High molecular weight hyaluronic acid inhibits advanced glycation endproduct-induced NF-kappa B activation and cytokine expression. FEBS Lett., 453, 283-287.

Noble, P.W., Lake, F.R., Henson, P.M. \& Riches, D.W. (1993) Hyaluronate activation of CD44 induces insulin-like growth factor-1 expression by a tumor necrosis factor-alpha-dependent mechanism in murine macrophages. J. Clin. Invest., 91, 2368-2377.

Okada, Y., Takeuchi, N., Tomita, K., Nakanishi, I. \& Nagase, H. (1989) Immunolocalization of matrix metalloproteinase 3 (stromelysin) in rheumatoid synovioblasts (B cells): correlation with rheumatoid arthritis. Ann. Rheum. Dis., 48, 645-653.

Postlethwaite, A.E., Lachman, L.B., Mainardi, C.L. \& Kang, A.H. (1983) Interleukin 1 stimulation of collagenase production by cultured fibroblasts. J. Exp. Med., 157, 801-806.

Punzi, L., Schiavon, F., Cavasin, F., Ramonda, R., Gambari, P.F. \& Todesco, S. (1989) The influence of intra-articular hyaluronic acid on PGE2 and cAMP of synovial fluid. Clin. Exp. Rheumatol., 7, 247-250.

Rydell, N. \& Balazs, E.A. (1971) Effect of intra-articular injection of hyaluronic acid on the clinical symptoms of osteoarthritis and on granulation tissue formation. Clin. Orthop., 80, 25-32.

Saari, H. \& Konttinen, Y.T. (1989) Determination of synovial fluid hyaluronate concentration and polymerisation by high performance liquid chromatography. Ann. Rheum. Dis., 48, 565-570.

Sasaki, K., Takagi, M., Mandelin, J., Takei, I., Santavirta, S., \& Ida, H. (2001) Quantitative analysis of mRNA expression of TIMPs in the periprosthetic interface tissue of loose hips by real-time PCR system. J. Biomed. Mater. Res., 58, 605-612.

Savani, R.C., Cao, G., Pooler, P.M., Zaman, A., Zhou, Z. \& DeLisser, H.M. (2001) Differential involvement of the hyaluronan (HA) receptors CD44 and receptor for HA-mediated motility in endothelial cell function and angiogenesis. $J$. Biol. Chem., 276, 36770-36778.

Shimizu, M., Yasuda, T., Nakagawa, T., Yamashita, E., Julovi, A.M., Hiramitsu, T. \& Nakamura, T. (2003) Hyaluronan inhibits matrix metallopro- 
teinases- 1 production by rheumatoid synovial fibroblasts stimulated by proinflammatory cytokines. J. Rheumatol., 30, 1164-1172.

Takagi, M., Santavirta, S., Ida, H., Ishii, M., Akimoto, K., Saotome, K. \& Konttinen, Y.T. (1998) The membrane-type-matrix metalloproteinase /matrix metalloproteinase-2/tissue inhibitor of metalloproteinase- 2 system in periprosthetic connective-tissue remodeling in loose total-hip prostheses. Lab. Invest., 78, 735-742.

Takei, I., Takagi, M., Santavirta, S., Ida, H., Ishii, M. \& Ogino, T. (2000) Messenger ribonucleic acid expression of 16 matrix metalloproteinases in bone-implant interface tissues of loose artificial hip joints. J. Biomed. Mater. Res., 52, 613-620.

Tobetto, K., Yasui, T., Ando, T., Hayaishi, M.,
Motohashi, N. \& Shinogi, M. (1992) Inhibitory effects of hyaluronan on [14C] arachidonic acid release from labeled human synovial fibroblasts. Jpn. J. Pharmacol., 60, 79-84.

Yasui, T., Akatsuka, M., Tobetto, K., Hayaishi, M. \& Ando, T. (1992) The effect of hyaluronan on interleukin-1 alpha-induced prostaglandin E2 production in human osteoarthritic synovial cells. Agents. Actions., 37, 155-6.

Yoshihara, Y., Nakamura, H., Obata, K., Yamada, H., Hayakawa, T. \& Fujikawa, K. (2000) Matrix metalloproteinases and tissue inhibitors of metalloproteinases in synovial fluids from patients with rheumatoid arthritis or osteoarthritis. Ann. Rheum. Dis., 59, 455-461. 